\title{
The effect of feeding whole wheat or rye and enzyme supplementation on laying performance, gizzard size and viscosity of intestinal digesta in hens
}

\section{Stefania Smulikowska, Ewa Święch and Anna Mieczkowska}

\author{
The Kielanowski Institute of Animal Physiology and Nutrition, \\ Polish Academy of Sciences \\ 05-110 Jablonna, Poland
}

(Received 20 August 1997; accepted 24 October 1997)

\begin{abstract}
The experiment was performed on 1296 Isa Brown laying hens aged 35 wecks. Hens were allocated to 6 groups and fed for 13 weeks on diets in which $30 \%$ of whole wheat or ground or whole rye was substituted by ground wheat. Rye diets were fed unsupplemented or supplemented with a feed enzyme (pentosanase and $\beta$-glucanase). Rye-containing diets (ground or whole) supported comparable productive performance to the wheat control dict in respect to hen-day egg production ( $81 \%$ on average) and feed conversion. Crop content and gizzard mass were significantly $(P \leqslant 0.05)$ larger in the group fed the whole wheat containing diet. Viscosity of digesta was significantly $(P \leqslant 0.05)$ higher on unsupplemented whole vs. ground rye diet $(11.5 \mathrm{vs} .5 .0 \mathrm{cP}$ in proximal and $28.5 \mathrm{vs} .16 .5 \mathrm{cP}$ in distal part of the small intestine, respectively) but diminished significantly (to 5.1 and $8.3 \mathrm{cP}$ ) after enzyme supplementation.
\end{abstract}

KEY WORDS: ryc, wheat, whole grain, hens, enzyme

\section{INTRODUCTION}

About $40 \%$ of ground rye may be incorporated into a balanced laying hen diet without deterioration of performance (Smulikowska and Buraczewski, 1986; Campbell and Campbell, 1989; Kuchta et al. 1991) and its low price makes rye an attractive ingredient of laying hen feed. It is well established that laying hens are 
able to adjust their intake of whole cereals and mash concentrate given together to meet their requirement for energy and protein. In a comprehensive review Forbes and Covasa (1995) described the use of various cereals in a free choice feeding system in poultry, but no investigation with the use of whole rye grain was mentioned. In the present study the response of laying hens to partial substitution of whole wheat grain, or ground or whole rye grain for ground wheat was examined. Rye diets were fed unsupplemented or supplemented with a feed enzyme in an effort to rectify any performance depression.

\section{MATERIAL AND METHODS}

The experiment was performed at the Poultry Farm of the Research Institute of Animal Production in Rossocha on 1296 Isa Brown laying hens. Hens were kept in floor pens on deep litter in a windowless poultry house, 65-67 hens per pen. At the start of the experiment the hens were 35 weeks old. During the preceding 15 weeks all of the hens were fed the control diet (Table 2) in mash form, and the average laying rate was $82.2 \%$. The lighting regime was $16 \mathrm{~h}$ of light per day, feed and water were supplied ad libitum. Granite grit $(5 \mathrm{~g} / \mathrm{hen})$ was supplied every second week. Three or 4 pens were allocated randomly to 6 dietary treatments and were fed diets that differed in type of cereal (wheat or rye) and its

TABLE 1

Chemical composition of rye and wheat used in diets, in \% of DM

\begin{tabular}{lcccccc}
\hline Cereal & Crude protein & Crude ash & Crude fat & Sugar & Starch & Dietary fibre* \\
\hline Rye & 11.35 & 1.49 & 2.32 & 6.07 & 59.71 & 19.06 \\
Wheat & 13.56 & 1.98 & 2.76 & 3.36 & 66.06 & 12.28 \\
\hline
\end{tabular}

* calculated as: $100-$ c. protein - c. ash - c. fat - sugar - starch

TABLE 2

Composition of diets, $\mathrm{g} / \mathrm{kg}$

\begin{tabular}{lcccccc}
\hline Ingredient & $\begin{array}{c}\text { Control } \\
\text { WGR }\end{array}$ & WWH & RGR & $\begin{array}{c}\text { RGR } \\
+\mathrm{E}\end{array}$ & RWH & $\begin{array}{c}\text { RWH } \\
+\mathrm{E}\end{array}$ \\
\hline Wheat ground (or whole) & 477 & $177(300)$ & 137 & 137 & 137 & 137 \\
Rye ground (or whole) & 0 & 0 & 300 & 300 & $(300)$ & $(300)$ \\
Fat concentrate (30\% fat) & 0 & 0 & 40 & 40 & 40 & 40 \\
Constant ingredients* & 523 & 523 & 523 & 523 & 523 & 523 \\
Enzyme** & - & - & - & 0.25 & - & 0.25 \\
\hline
\end{tabular}

* supplied per kg of diet, g: ground maize 190; rapeseed meal 00 - 50; soyabean meal 130; meat meal 40; cgg shells 20; limestone 50; Kolbiomix 20; mineral-vitamin premix 23

** Endofeed (GNC Bioferm) 
form (ground or whole grain). The chemical composition of wheat and rye used in the experiment was determined according to standard methods (AOAC, 1990) and is given in Table 1, the composition of the diets in Table 2. The control diet (WGR) contained ground wheat; in the experimental diets, $30 \%$ of whole wheat grain (WWH), or $30 \%$ of ground (RGR) or whole (RWH) rye grain was substituted for ground wheat. Whole grain was mixed with the other components of the diet and given in the same troughs. All rye diets were fortified with $1.2 \%$ of mixed fat to equalize the level of energy with the control diet. Rye diets were fed unsupplemented or supplemented with feed enzyme (Endofeed, GNC Bioferm) containing 2250 units of pentosanase and 1000 units of $\beta$-glucanase per gram according to the declaration of the producer. The experimental diets were introduced gradually; every 4 days $1 / 4$ of the control diet was substituted by experimental diets.

Experimental diets were fed for 13 weeks, egg number and egg mass were recorded daily, feed consumption was measured weekly for each pen and feed conversion efficiency data calculated. Twice during the experiment (at 39 and 46 weeks of life; weeks 4 and 11 of the experiment) 15 eggs were randomly selected from each experimental group. On the next day the weight of each egg was recorded $(\mathrm{W})$, and the breakage strength of the shell measured by the quasi-static compression technique. Later the eggs were broken, the colour of yolks compared with LaRoche colour disc, the height of the egg white was measured $(\mathrm{H})$ and the Haugh unit value $(\mathrm{LH})$ calculated according to the equation:

$$
\mathbf{L H}=100 \lg \left(\mathbf{H}-\mathrm{W}^{0.37}+7.6\right)
$$

After conclusion of the experiment 10 hens from each group were randomly selected, weighed, killed by decapitation, the digestive tract was removed, crop, proventriculus, gizzard, duodenum, caeca, proximal (from the duodenum to Meckel's diverticulum) and distal (from Meckel's diverticulum to the ileo-caeco-colic junction) parts of small intestine weighed with and without their contents. Intestinal contents were immediately centrifuged at $10.000 \mathrm{x} \mathrm{g}$ for 10 min, the supernatant withdrawn and its viscosity determined using a Brookfield digital viscometer (Model LVDV-II +CP), maintained at $40^{\circ} \mathrm{C}$.

Data concerning performance, weight of parts of the digestive tract and their contents (relative to $100 \mathrm{~g}$ live body weight) and viscosity of digesta in the proximal and distal parts of the small intestine were analyzed using one-way analysis of variance (Statgraphics Plus ver. 7 software).

\section{RESULTS AND DISCUSSION}

Hens offered feed containing $30 \%$ wheat as whole grain produced $4 \%$ more eggs but consumed $8 \%$ more feed than in the control group $(P \leqslant 0.05)$ (Table 3 ). 
TABLE 3

Effect of incorporating of ground (WGR) or whole (WWH) wheat, ground (RGR) or whole (RWH) rye and enzyme $(+E)$ on productive performance of laying hens and monetary return

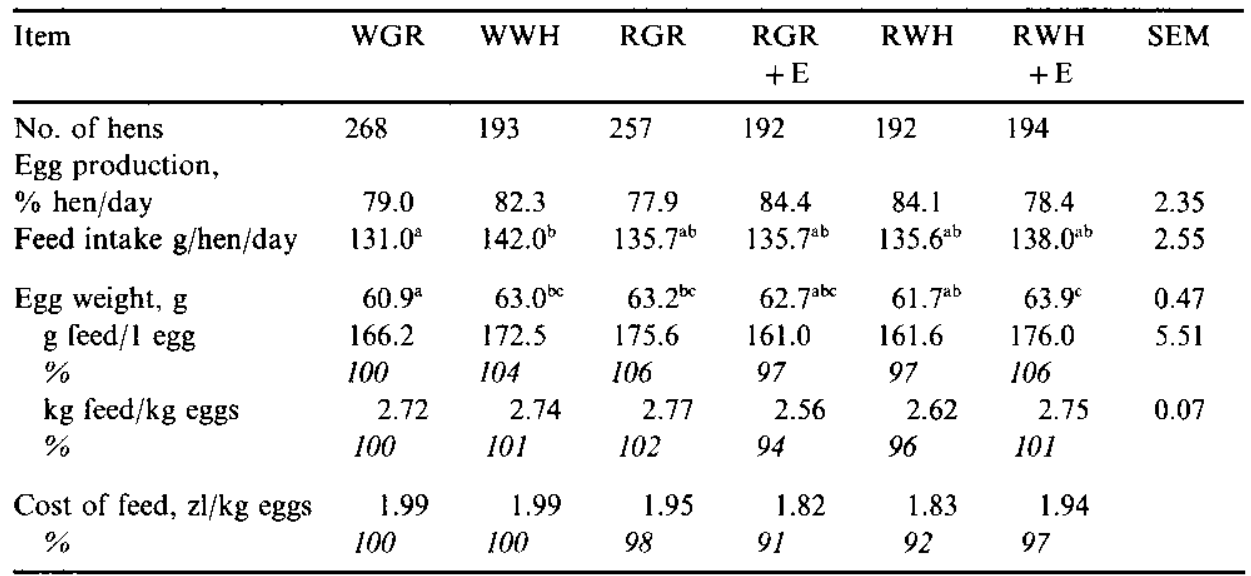

$a, b-$ means in rows without superscripts or having the same superscripts are not significantly different at $P \leqslant 0.05$

As the average egg mass was significantly $(\mathrm{P} \leqslant 0.05)$ higher in the WWH group, feed utilization per kg eggs was in this group nearly equal to the control. Feed intake was rather high in all groups, between 131 and $142 \mathrm{~g} / \mathrm{hen} / \mathrm{day}$, the tendency to overeat may have been caused by the very low outside temperatures $\left(-25^{\circ} \mathrm{C}\right)$ during the last month of experiment. Substitution of $30 \%$ rye (ground or whole) for wheat caused an increase in daily feed consumption by $4 \%$ on average. Enzyme supplementation of the diet containing ground rye $(R G R+E)$ caused an increase in egg production and the amount of feed used per $1 \mathrm{~kg}$ eggs was in this group $8 \%$ lower than in the unsupplemented (RGR) group and $6 \%$ lower than in the control (WGR) group.

In previous experiments (Smulikowska and Buraczewski, 1986, 1989; Kuchta et al., 1991; Smulikowska et al. 1996) the eggs of rye-fed hens were on average 0.7-2 g lighter, however rye-containing diets were not fortified with additional fat, which may have resulted not only in decreased energy density of the diets, but also in minor linoleic acid deficiency. The first sign of linoleic acid deficiency in laying hens is a decrease in egg size (Menge et al., 1965). In the present experiment the eggs from rye-fed hens were on average $2 \mathrm{~g}$ heavier than in the control group (Table 4). It seems that due to fat fortification of the rye diets, not only was the energy level increased, but also the level of linoleic acid was adequate to requirements.

It can be seen that little difference in egg quality measurements was noted in response to the type of cereal or its form (Table 4). Interior egg quality was good as the LH value was high and did not differ among groups. A lower breakage 
TABLE 4

Egg quality measured at 4 and 11 week of experiment ( 39 and 46 week of life)

\begin{tabular}{|c|c|c|c|c|c|c|c|c|}
\hline Item & $\begin{array}{l}\text { Week } \\
\text { of life }\end{array}$ & WGR & WWH & RGR & $\begin{array}{c}\text { RGR } \\
+\mathrm{E}\end{array}$ & RWH & $\begin{array}{c}\text { RWH } \\
+\mathrm{E}\end{array}$ & SEM \\
\hline \multirow[t]{2}{*}{ Egg weight, g } & 39 & $59.5^{\mathrm{a}}$ & $61.3^{\mathrm{ab}}$ & $62.2^{b}$ & $62.0^{\mathrm{b}}$ & $61.9^{b}$ & $62.5^{b}$ & 0.59 \\
\hline & 46 & 64.9 & 63.7 & 64.1 & 65.5 & 63.7 & 64.5 & 0.54 \\
\hline \multirow[t]{2}{*}{ LH } & 39 & 82.4 & 80.3 & 80.5 & 82.4 & 82.9 & 83.3 & 1.23 \\
\hline & 46 & 83.0 & 82.9 & 84.6 & 83.0 & 82.4 & 82.6 & 0.96 \\
\hline \multirow[t]{2}{*}{ Breakage strenght, $\mathrm{kg}$} & 39 & $2.00^{\mathrm{b}}$ & $1.60^{\mathrm{a}}$ & $1.77^{\mathrm{ab}}$ & $1.63^{\mathrm{ab}}$ & $1.50^{\mathrm{a}}$ & $1.83^{\mathrm{ab}}$ & 0.09 \\
\hline & 46 & $1.10^{\mathrm{ab}}$ & $0.97^{\mathrm{ab}}$ & $0.93^{\mathrm{a}}$ & $1.30^{\mathrm{ab}}$ & $1.36^{\mathrm{b}}$ & $1.33^{\mathrm{ab}}$ & 0.11 \\
\hline \multirow[t]{2}{*}{ Yolk colour } & 39 & $3.33^{\mathrm{ab}}$ & $3.20^{\mathrm{ab}}$ & $3.40^{\mathrm{h}}$ & $2.60^{3}$ & $3.00^{\mathrm{ab}}$ & $2.93^{\mathrm{ab}}$ & 0.19 \\
\hline & 46 & 4.26 & 4.80 & 4.73 & 4.67 & 4.40 & 4.40 & 0.25 \\
\hline
\end{tabular}

$a, b-$ means in rows without superscripts or having the same superscripts are not significantly different at $P \leqslant 0.05$

strength of the egg shell $(\mathrm{P} \leqslant 0.05)$ was recorded at the first measurement in groups WWH and RWH, in the second measurement the lowest value was noted in groups WWH and RGR (Table 4). Yolk colour ranged on average between 2.6 and 4.8 on the LaRoche scale, significantly lighter were egg yolks of group $\mathrm{RGR}+\mathrm{E}$, but only in the first measurement. The colour of yolks in all other groups fed rye-containing diets was acceptable, as the rations contained feeds rich in xanthophylls (maize and Kolbiomix). In previous experiments (Smulikowska and Buraczewski, 1986; Smulikowska at al., 1996) hens fed rye diets, which did not contain natural sources of xanthophylls, laid eggs with very pale yolks.

The significantly $(P \leqslant 0.05)$ bigger crop content in birds fed whole vs. ground wheat indicates that the transit time of whole grain from crop to the proventriculus may be delayed. Similar tendencies were observed in hens fed whole vs. ground rye (Table 5). Feeding whole wheat significantly increased $(\mathrm{P} \leqslant 0.05)$ the relative gizzard weight in comparison with the control group, but this was partly due to higher fat tissue accumulation. The differences in the relative size of the gizzard in groups fed whole vs. ground rye were smaller and nonsignificant. Increased relative weight of the gizzard in birds fed whole grain had been reported previously (Forbes and Covasa, 1996; Svihus et al., 1997). Species and form of grain did not significantly affect the relative weights of other parts of the digestive tract or their contents, nor the final live body weight of hens (1885 $\mathrm{g}$ on average).

It is interesting that supplementation of rye-containing diets with pentosanase and $\beta$-glucanase had not affected small intestinal digesta viscosity in birds fed ground rye but lowered it significantly $(P \leqslant 0.05)$ in the proximal (by $55 \%)$ and distal (by $70 \%$ ) parts of the small intestine in birds fed whole rye grain (Table 5). 
TABLE 5

Weight of parts of digestive tract and their contents (as \% of live body weight (LBW)) and viscosity of digesta in proximal and distal part of small intestine (SIDV) in $\mathrm{cP}$

\begin{tabular}{|c|c|c|c|c|c|c|c|c|}
\hline \multicolumn{2}{|l|}{ Item } & \multirow{2}{*}{$\begin{array}{c}\text { WGR } \\
1884\end{array}$} & \multirow{2}{*}{$\begin{array}{c}\text { WWH } \\
1877\end{array}$} & \multirow{2}{*}{$\begin{array}{c}\text { RGR } \\
1952\end{array}$} & \multirow{2}{*}{$\begin{array}{r}\text { RGR } \\
+\mathrm{E} \\
1895\end{array}$} & \multirow{2}{*}{$\begin{array}{r}\text { RWH } \\
1806\end{array}$} & \multirow{2}{*}{$\begin{array}{c}\begin{array}{c}\text { RWH } \\
+E\end{array} \\
1906\end{array}$} & \multirow{2}{*}{$\begin{array}{c}\text { SEM } \\
54\end{array}$} \\
\hline $\mathrm{LBW}, \mathrm{g}$ & & & & & & & & \\
\hline \multirow[t]{2}{*}{ Crop } & empty & 0.33 & 0.34 & 0.38 & 0.36 & 0.37 & 0.34 & 0.02 \\
\hline & content & $0.37^{a}$ & $1.16^{\mathrm{b}}$ & $0.40^{\mathrm{ab}}$ & $0.62^{\mathrm{ab}}$ & $0.80^{\mathrm{ab}}$ & $0.75^{\mathrm{ab}}$ & 0.19 \\
\hline \multirow[t]{2}{*}{ Proventriculus } & empty & 0.39 & 0.44 & 0.42 & 0.38 & 0.41 & 0.40 & 0.02 \\
\hline & content & 1.00 & 0.02 & 0.02 & 0.01 & 0.01 & 0.02 & 0.41 \\
\hline \multirow[t]{2}{*}{ Gizzard } & empty & $1.55^{\mathrm{a}}$ & $2.03^{\mathrm{b}}$ & $1.69^{\mathrm{a}}$ & $1.61^{\mathrm{a}}$ & $1.67^{\mathrm{a}}$ & $1.62^{\mathrm{a}}$ & 0.08 \\
\hline & content & 0.67 & 0.85 & 0.69 & 0.74 & 0.81 & 0.73 & 0.06 \\
\hline \multirow{2}{*}{ Duodenum } & empty & 0.46 & 0.49 & 0.48 & 0.53 & 0.53 & 0.53 & 0.02 \\
\hline & content & 0.26 & 0.32 & 0.25 & 0.25 & 0.30 & 0.34 & 0.03 \\
\hline \multirow[t]{2}{*}{ Small intestine } & empty & 1.87 & 2.03 & 1.98 & 2.05 & 1.93 & 1.95 & 0.04 \\
\hline & content & 1.97 & 1.80 & 1.89 & 1.78 & 2.05 & 2.09 & 0.11 \\
\hline Caeca & full & 0.78 & 0.81 & 0.86 & 0.82 & 0.85 & 0.86 & 0.04 \\
\hline Liver & & 2.24 & 2.22 & 2.07 & 2.13 & 2.37 & 2.38 & 0.11 \\
\hline Pancreas & & 0.20 & 0.21 & 0.21 & 0.22 & 0.23 & 0.21 & 0.01 \\
\hline Proximal SIDV & & $2.5^{\mathrm{a}}$ & $2.9^{a}$ & $5.0^{\mathrm{a}}$ & $7.0^{\mathrm{ab}}$ & $11.5^{\mathrm{b}}$ & $5.1^{\mathrm{a}}$ & 1.19 \\
\hline Distal SIDV & & $3.3^{3}$ & $3.4^{\mathrm{a}}$ & $16.5^{\mathrm{ab}}$ & $17.8^{\mathrm{ab}}$ & $28.5^{\mathrm{b}}$ & $8.3^{\mathrm{a}}$ & 4.61 \\
\hline
\end{tabular}

$\mathrm{a}, \mathrm{b}$ - means in rows without superscripts or having the same superscripts are not significantly different at $\mathbf{P} \leqslant 0.05$

The increased crop content of birds fed whole grain indicates that the passage of whole rye grain through the crop and gizzard may be delayed. Due to the longer time of passage, more rye arabinoxylans may be solubilized, resulting in higher viscosity of digesta. This means, however, that the added enzymes may also have a longer time and better opportunity to hydrolyze the soluble arabinoxylans of rye. It should be noted that even after enzyme supplementation, the viscosity of small intestinal digesta in birds fed rye-containing diets was higher than in birds fed wheat diets (Table 5).

The substitution of whole for ground wheat did not substantially improve the economy of the feed, but substitution of $30 \%$ rye by wheat reduced the cost of feed per kg of eggs by $2-9 \%$. The most substantial reduction can be seen in group fed the diet containing ground rye supplemented with feed enzyme (Table 3 ).

It may be concluded that whole rye grain, included in moderate quantities, may be an economically effective substitute of more expensive cereals in laying hen rations. Supplementation of rye diets with feed enzyme may have a favourable effect on economic returns. 


\section{ACKNOWLEDGMENTS}

The authors wish to thank The Andrew W. Mellon Foundation for financial support of this study, Agrimax for the feed enzyme provided for this experiment and M. Słonecki of Poultry Farm Rossocha for excellent technical assistance.

\section{REFERENCES}

AOAC, 1990. Official Methods of Analysis of the Association of Official Analytical Chemists. 15th Edition, Chapter 32, Washington, DC

Campbell G.L., Campbell L.D., 1989. Rye as a replacement for wheat in laying hen diets. Can. J. Anim. Sci. 69, 1041-1047

Forbes J.M., Covasa M., 1995. Application of diet selection by poultry with particular reference to whole cereals. World's Poultry Sci. J. 51, 149-165

Kuchta M., Koreleski J., Zegarek Z., 1991. Feed enzymes of pectinolytic activity in laying hen diets (in Polish). Rocz. Nauk Zoot. 18, 195-206

Menge H., Calvert C.C., Denton C.A., 1965. Further studies on the effect of linoleic acid on reproduction in the hen. J. Nutr. 86, 115-121

Smulikowska S., Buraczewski S., 1986. Effect of rye on laying hen performance and egg quality. Proceedings of 7th European Poultry Conference, Paris (France), Vol. 1, pp. 464-467

Smulikowska S., Rutkowski A., Mieczkowska A., 1996. How to use rye in laying hen diets (in Polish). Polskie Drob. 11, 9-12

Svihus B., Herstad O., Newman C.W., Newman R.K., 1997. Nutritional impacts of using whole or ground barley to enzyme supplemented broiler diets. Proceedings of 1 I th European Symposium on Poultry Nutrition, Faaborg (Denmark), pp. 267-269

\section{STRESZCZENIE}

Wpływ żywienia kur nieśnych mieszankami zawierającymi cale ziarno pszenicy lub żyta oraz dodatek enzymu na wyniki produkcyjne, masẹ przewodu pokarmowego oraz lepkość treści jelita cienkiego

Doświadczenie przeprowadzono na 1296 kurach Isa Brown w wieku 35 tygodni, podzielonych na 6 grup. Kury przez 13 tygodni żywiono mieszankami, w których $30 \%$ śruty pszennej zastępowano śrutą żytnią lub całym ziarnem pszenicy lub żyta. Mieszanki zawierające ży to podawano nieuzupełnione lub $z$ dodatkiem enzymu paszowego (zawierającego pentozanazy i $\beta$-glukanazę). Nieśność i wykorzystanie paszy przez kury żywione mieszankami zawierającymi żyto, zarówno śrutowane jak i podawane w całości, nie różniły się istotnie od wyników kur żywionych mieszankami zawierającymi pszenicę. Włączenie do micszanki całego ziarna pszenicy spowodowało istotne $(P \leqslant 0,05)$ zwiększenie zawartości wola i masy mielca kur. Lepkość treści jelita cienkiego kur żywionych mieszanką zawierającą całe ziarno żyta była istotnie $(\mathrm{P} \leqslant 0,05)$ większa niż u kur żywionych mieszanką zawierająca ży to śrutowane ( 11,5 vs $5,0 \mathrm{cP}$ w przedniej i 28,5 vs $16,5 \mathrm{cP}$ w tylnej części jelita), lecz po dodaniu preparatu enzymatycznego uległa istotnemu obniżeniu (odpowiednio do 5,1 i 8,3 cP). 